\title{
ANTIBACTERIAL ACTIVITY OF CURCUMENOL FROM RHIZOMES OF INDONESIAN CURCUMA AERUGINOSA (ZINGIBERACEAE)
}

\author{
D. U. C. Rahayu', Hartono ${ }^{2}$, and P. Sugita ${ }^{2, *}$ \\ ${ }^{1}$ Department of Chemistry, Universitas Indonesia, \\ Kampus UI Depok-16424, (West Java) Indonesia \\ ${ }^{2}$ Department of Chemistry, Institut Pertanian Bogor, \\ Kampus IPB Dramaga Bogor-16680, (West Java) Indonesia \\ *E-mail : purwantiningsih@ apps.ipb.ac.id; atiek_ps@yahoo.com
}

\begin{abstract}
The rhizomes of Curcuma aeruginosa (Zingiberaceae), locally known as Teти Hitam, is usually used as a traditional medicine. The bioactive compounds in this plant were known to have antibacterial activities. However, information regarding bioactive compounds on antibacterial activity contained in C. aeruginosa rhizomes is still limited. In continuing our study on Indonesian medicinal plants, the isolation of bioactive compounds from $C$. aeruginosa growing in Indonesia had been conducted. Curcumenol had been isolated from the methanol extract of $C$. aeruginosa rhizomes by using extraction methods and several chromatography techniques, i.e. vacuum liquid, radial, and preparative thin layer chromatography. Furthermore, this compound had been elucidated based on one-dimensional NMR $\left({ }^{1} \mathrm{H}\right.$ and $\left.{ }^{13} \mathrm{C}\right)$ and MS. The preliminary antibacterial assay of methanol extract of $C$. aeruginosa rhizomes on Salmonella typhi and Escherichia coli showed moderate activity with an inhibition zone of $7 \mathrm{~mm}$ (inhibition index of 1.17 ) and $6 \mathrm{~mm}$ (inhibition index of 1.00), in $50 \mathrm{ppm}$, respectively. Moreover, curcumenol also exhibited moderate activity in $50 \mathrm{ppm}$ with $8 \mathrm{~mm}$ of inhibition zone (1.33 of inhibition index) on $S$. typhi while on E. coli showed weak activity in $50 \mathrm{ppm}$ with $4 \mathrm{~mm}$ of inhibition zone ( 0.67 of inhibition index). However, both the methanol extract of $C$. aeruginosa rhizomes and curcumenol were inactive on Bacillus cereus and Staphylococcus aureus. It can be suggested that curcumenol played an important contribution to an antibacterial activity toward Gram-negative bacteria (S. typhi and $E$. coli) in C. aeruginosa rhizomes.

Keywords: antibacterial, Bacillus cereus, Curcuma aeruginosa, Escherichia coli, curcumenol, Salmonella typhi, Staphylococcus aureus.
\end{abstract}

@ RASĀYAN. All rights reserved

\section{INTRODUCTION}

Indonesia has the highest biodiversity in the world reaching $11 \%$ of plants species found in the Earth's surface. Eighty percent of them are known as medicinal plants, but only around 1,000 species which have been used as traditional medicines. ${ }^{1}$ One of the species of Curcuma genus (Zingiberaceae), C. aeruginosa, locally known as Temu Hitam, is usually used in traditional medicines for treating various ailments. ${ }^{2}$ The previous researches reported that the variety of compounds in this plants extract, such as phenolic compounds, flavones, lignans, and terpenes derivatives, have also been known to have antibacterial and anticancer activities. ${ }^{3-9}$ However, there are no recent studies that have been reported regarding bioactive compounds on antibacterial activity contained in C. aeruginosa rhizomes. Here, we focused on the isolation of bioactive compound on antibacterial activity towards Gram-negative bacteria (S. typhi and E. coli) and Gram-positive bacteria (B. cereus and $S$. aureus) and found that curcumenol is a moderate-active compound isolated from $C$. aeruginosa rhizomes.

\section{EXPERIMENTAL}

General Experimental Procedures

${ }^{1} \mathrm{H}$ NMR (500 MHz) and ${ }^{13} \mathrm{C}$ NMR (125 MHz) spectra were recorded in $\mathrm{CDCl}_{3}$ using Agilent 500 instrument. Chemical shift references were obtained by addition of TMS. MS spectra were measured using 
GC/MS Agilent 19091S-433 instrument. Melting point was determined using Fisher-Johns melting point apparatus. Vacuum liquid chromatography was performed using Si $60 \mathrm{G}$ (Merck) for column packed and Si 60 (0.2-0.5 mm) (Merck) for sample adsorbed. Radial chromatography was carried out using Si $60 \mathrm{PF}_{254}$ containing gypsum (Merck). Si $60 \mathrm{GF}_{254}$ (Merck) was used for preparative TLC. For TLC analysis, precoated silica gel plates (Merck Si $60 \mathrm{GF}_{254}, 0.25 \mathrm{~mm}$ thickness) and $\mathrm{Ce}\left(\mathrm{SO}_{4}\right)_{2} .4 \mathrm{H}_{2} \mathrm{O} 1.5 \%$ in $\mathrm{H}_{2} \mathrm{SO}_{4} 2 \mathrm{~N}$ as apparition stain reagent were used. Antibacterial activity was conducted using disc diffusion methods. Four bacteria, i.e. S. typhi, E. coli, B. cereus, and S. aureus from Departement of Biology IPB were used for antibacterial activity assays. Tetracycline was selected as positive control while DMSO was used as negative control. Inhibition index was measured by the following equation (Equation 1).

$$
\text { Inhibition index }=\frac{\text { Inhibition zone of sample }}{\text { Paper disc diameter }}
$$

\section{Plant Materials}

C. aeruginosa rhizomes were collected from Pusat Studi Biofarmaka Tropika (Trop BRC) LPPM-IPB, West Java, Indonesia in January 2017.

\section{Extraction and Isolation}

Dried powdered $C$. aeruginosa rhizomes $(1.01 \mathrm{~kg})$ were exhaustively extracted three times with $\mathrm{MeOH}$ at room temperature. After filtering and evaporating the solvent, $118.74 \mathrm{~g}$ crude extract was yielded. The crude extract ( $30 \mathrm{~g}$ ) was then fractionated using vacuum liquid chromatography with $n$-hexane:EtOAc as a solvent to obtain seven major fractions (A-H). Fraction C (3.05 g) was separated by using repeated vacuum liquid chromatography with $n$-hexane:EtOAc as a solvent yielding seven sub-fractions (C1-C7). Curcumenol (6.0 mg; $0.59 \%$ yield) was isolated from sub-fraction C6 after separating and purifying by using radial chromatography with $n$-hexane and increasing polarity as a solvent then followed by using preparative TLC with $n$-hexane: $\mathrm{CHCl}_{3} 3: 7$ as a solvent.

Curcumenol, $\mathrm{C}_{15} \mathrm{H}_{22} \mathrm{O}_{2}$; white powder; melting point: $117-119.5^{\circ} \mathrm{C} ; R f$ value: 0.875 in $n$-hexane: $\mathrm{CHCl}_{3}$ 3:7; ${ }^{1} \mathrm{H}$ NMR $\left(\mathrm{CDCl}_{3}\right): 5.76(1 \mathrm{H}, s, \mathrm{H}-9), 4.53(1 \mathrm{H}, b r s,-\mathrm{OH}$ in C-8), $2.88(1 \mathrm{H}, s, \mathrm{H}-6 \mathrm{a}), 2.66(1 \mathrm{H}, d, \mathrm{~J}=$ 15.8, H-6b), 2.00 (1H, $m, \mathrm{H}-1), 1.93$ (4H, $m, \mathrm{H}-2, \mathrm{H}-3), 1.89$ (1H, $m, \mathrm{H}-4), 1.80$ (3H, $s, \mathrm{H}-12), 1.65$ (3H, $s$, $\mathrm{H}-13), 1.59(3 \mathrm{H}, s, \mathrm{H}-15)$, and $1.03(3 \mathrm{H}, d, \mathrm{~J}=6.35, \mathrm{H}-14) ;{ }^{13} \mathrm{C} \mathrm{NMR}\left(\mathrm{CDCl}_{3}\right): 139.3(\mathrm{C}-7), 137.5(\mathrm{C}-10)$, 125.8 (C-9), 122.4 (C-11), 101.7 (C-8), 85.8 (C-5), 51.4 (C-1), 40.5 (C-4), 37.3 (C-6), 31.4 (C-3), 27.8 (C2), 22.5 (C-12), 21.1 (C-15), 19.0 (C-13), and 12.0 (C-14); MS (m/z): 234.

\section{RESULTS AND DISCUSSION}

C. aeruginosa, belonging to Zingeberaceae family, was chosen for present study by an analysis of the published literature that showed that this species is usually used as a traditional medicine and its extract had antibacterial activity. ${ }^{2,5,7}$ However, there are no recent studies have been reported on antibacterial bioactive compounds from Indonesian $C$. aeruginosa.

Initially, dried powdered of $C$. aeruginosa rhizomes was extracted with $\mathrm{MeOH}$. The $\mathrm{MeOH}$ extract was tested on antibacterial activity and demonstrated moderate activity toward $S$. typhi and E. coli with an inhibition zone of 7 and $6 \mathrm{~mm}$, respectively, (Table 1) and inhibition index of 1.17 and 1.00, respectively, (Fig.-1), in $50 \mathrm{ppm}$. In contrast, this extract was inactive toward B. cereus and S. aureus. This antibacterial activity, especially toward Gram-negative bacteria ( $S$. typhi and E. coli), enriched the information regarding Curcuma extract having antibacterial activities. Previous studies had been reported that besides $C$. aeruginosa extract, the others Curcuma extract also had antibacterial activity, such as $C$. heyneana, $C$. zedoaria, C. longa, and C. xanthorrhiza. ,, $710-14$ This extract was then subjected to various chromatography techniques resulting in one known guaiane-type sesquiterpenes, curcumenol (Fig.-2).

The structure elucidation of curcumenol was carried out based on one-dimensional NMR $\left({ }^{1} \mathrm{H}\right.$ and $\left.{ }^{13} \mathrm{C}\right)$ and also compared with previously reported data ${ }^{4,8,15}$. Based on ${ }^{13} \mathrm{C}$ NMR spectra, there were 15 signals of carbon which correspond to sesquiterpenes derivatives, i.e. $4 \mathrm{C}-s p^{2}$ from alkenes double bonds in $\delta_{\mathrm{C}}$ of 122.4-139.3 ppm, 2 C-sp $p^{3}$ bonded to $\mathrm{O}$ given the de-shielding $\delta_{\mathrm{C}}$ of $85.8-101.7 \mathrm{ppm}$, and $9 \mathrm{C}-s p^{3}$ signals in 
$\delta_{\mathrm{C}}$ of 12.0-51.4 ppm. ${ }^{1} \mathrm{H}$ NMR spectra showed that this compound had 22 signals which correspond to $1 \mathrm{H}-$ $\mathrm{Csp} p^{2}$ alkenes in $\delta_{\mathrm{H}}$ of $5.76 \mathrm{ppm}(1 \mathrm{H}, s), 1 \mathrm{H}$ bonded to hydroxyl group in $\delta_{\mathrm{H}}$ of $4.53 \mathrm{ppm}(1 \mathrm{H}, b r s), 2 \mathrm{H}-$ $\mathrm{Csp} p^{3}$ bonded to $\mathrm{Csp}^{2}$ (electron withdrawing group) yielded the de-shielding $\delta_{\mathrm{H}}$ of $2.66-2.88 \mathrm{ppm}$, and the rest were $\mathrm{H}-\mathrm{Cs} p^{3}$ in $\delta_{\mathrm{H}}$ of 1.03-2.00 ppm. The molecular formula concluded from NMR spectral data was $\mathrm{C}_{15} \mathrm{H}_{22} \mathrm{O}_{2}$ with 5 degree of unsaturated, i.e. 2 alkenes double bonds and 3 cyclics. Therefore, it was no doubtful that the isolated compound was curcumenol. Curcumenol previously isolated from Malaysian $C$. zedoaria and also Thailand and Vietnam C. aeruginosa $a^{4,8,15}$.

Table-1: Antibacterial activity of $\mathrm{MeOH}$ extract of C. aeruginosa rhizomes and curcumenol towards S. typhi, E. coli, B. cereus, and S. aureus.

\begin{tabular}{|c|c|c|c|c|c|}
\hline \multirow{2}{*}{ Bacteria } & \multirow{2}{*}{ Conc. (ppm) } & \multicolumn{2}{|c|}{ Inhibition Zone $(\mathrm{mm})^{\mathrm{a}, \mathrm{b}}$} & \multicolumn{2}{|c|}{ Activity Classification $^{\mathrm{c}, 16}$} \\
\hline & & $\mathrm{MeOH}$ extract & Curcumenol & $\mathrm{MeOH}$ extract & Curcumenol \\
\hline \multirow{5}{*}{$\begin{array}{l}\text { S. typhi } \\
\text { (Gram -) }\end{array}$} & 3.12 & 4 & 4 & Weak & Weak \\
\hline & 6.25 & 5 & 4 & Moderate & Weak \\
\hline & 12.50 & 6 & 5 & Moderate & Moderate \\
\hline & 25.00 & 6 & 6 & Moderate & Moderate \\
\hline & 50.00 & 7 & 8 & Moderate & Moderate \\
\hline \multirow{5}{*}{$\begin{array}{c}\text { E. coli } \\
\text { (Gram -) }\end{array}$} & 3.12 & 5 & 5 & Moderate & Moderate \\
\hline & 6.25 & 5.5 & 4 & Moderate & Weak \\
\hline & 12.50 & 4 & 4 & Weak & Weak \\
\hline & 25.00 & 5.5 & 3.5 & Moderate & Weak \\
\hline & 50.00 & 6 & 4 & Moderate & Weak \\
\hline \multirow{5}{*}{$\begin{array}{c}\text { B. cereus and } S \text {. } \\
\text { aureus } \\
(\text { Gram }+)\end{array}$} & 3.12 & $\sim 0$ & $\sim 0$ & Inactive & Inactive \\
\hline & 6.25 & $\sim 0$ & $\sim 0$ & Inactive & Inactive \\
\hline & 12.50 & $\sim 0$ & $\sim 0$ & Inactive & Inactive \\
\hline & 25.00 & $\sim 0$ & $\sim 0$ & Inactive & Inactive \\
\hline & 50.00 & $\sim 0$ & $\sim 0$ & Inactive & Inactive \\
\hline
\end{tabular}

a Inhibition zone was measured in compared with paper disk diameter $(6 \mathrm{~mm})$.

b Inhibition zones of positive control (tetracycline) were 49, 44, 14, and $14 \mathrm{~mm}$ for S. typhi, E. coli, B. cereus, and $S$. aureus, respectively, in $100 \mathrm{ppm}$. Tetracycline classified as very strong activity toward $S$. typhi and E. coli and strong activity toward B. cereus and S. aureus., ${ }^{c} 16$ Negative control (DMSO) did not show any activity on four bacteria. All inhibition zones for positive control were also measured in compared with paper disk diameter (6 mm).

c Activity classification based on W. W. Davis and T. R. Stout, 1971: weak (<5 mm), moderate (5-10 mm), strong $(10-20 \mathrm{~mm})$, and very strong $(>20 \mathrm{~mm})$

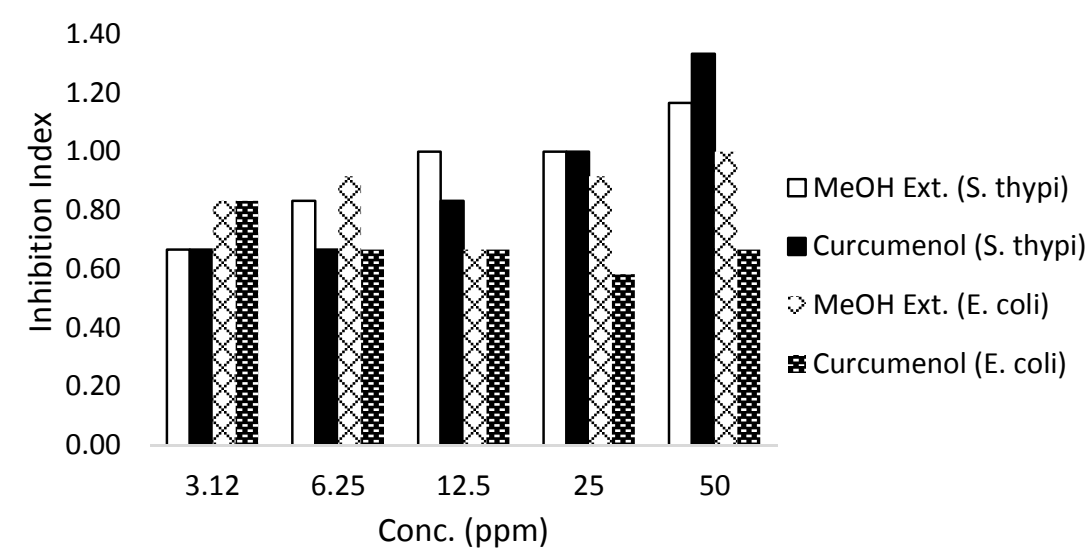

Fig.-1: Inhibition index toward S. typhi and E. coli from $\mathrm{MeOH}$ extract and curcumenol

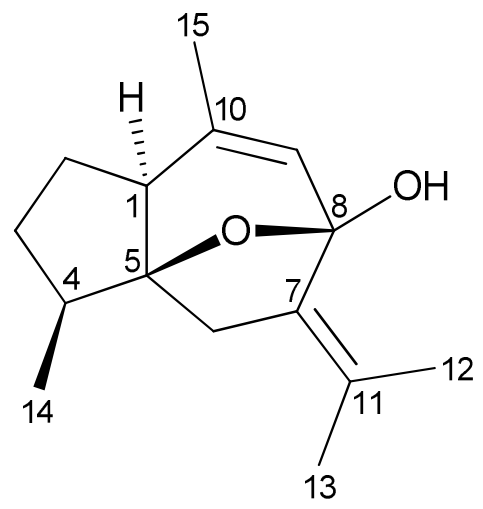

Fig.-2: The structure of curcumenol

The ability to inhibit bacterial growth toward S. typhi, E. coli, B. cereus, and S. aureus of curcumenol using disc diffusion method had been examined. This assay is based on the formation of clear zone around the paper disc. This is the first report on antibacterial activity toward S. typhi, E. coli, B. cereus, and S. aureus 
of curcumenol. Curcumenol exhibited moderate activity in $50 \mathrm{ppm}$ with $8 \mathrm{~mm}$ of inhibition zone (Table-1) and 1.33 of inhibition index (Fig.-1) on S. typhi and showed weak activity towards E. coli with $4 \mathrm{~mm}$ of inhibition zone (Table-1) and 0.67 of inhibition index (Fig.-1). In contrast, this compound was inactive toward B. cereus and S. aureus.

Figure-1 showed that increasing concentration mostly will increase the inhibition index. Inhibition index of curcumenol towards $S$. typhi was higher than E. coli. Inhibition index of curcumenol in $\leq 25 \mathrm{ppm}$ showed a similarity inhibition with $\mathrm{MeOH}$ extract, while in $>25 \mathrm{ppm}$ showed higher inhibition than $\mathrm{MeOH}$ extract on S. typhi. It can be suggested that curcumenol played an important contribution to an antibacterial activity toward Gram-negative bacteria (S. typhi and E. coli) in C. aeruginosa rhizomes.

\section{CONCLUSION}

Curcumenol had been isolated from $\mathrm{MeOH}$ extract of Indonesian C. aeruginosa rhizomes. Formerly, this compound was obtained from Malaysian C. zedoaria and Thailand and Vietnam C. aeruginosa. The antibacterial assay of $\mathrm{MeOH}$ extract of $C$. aeruginosa rhizomes on $S$. typhi and $E$. coli showed moderate activity in $50 \mathrm{ppm}$ with an inhibition zone of $7 \mathrm{~mm}$ (inhibition index of 1.17) and $6 \mathrm{~mm}$ (inhibition index of 1.00), in $50 \mathrm{ppm}$, respectively. Curcumenol also exhibited moderate activity in $50 \mathrm{ppm}$ with $8 \mathrm{~mm}$ of inhibition zone (1.33 of inhibition index) on $S$. typhi while on $E$. coli showed weak activity in 50 ppm with $4 \mathrm{~mm}$ of inhibition zone ( 0.67 of inhibition index). However, both the methanol extract of $C$. aeruginosa rhizomes and curcumenol were inactive on $B$. cereus and $S$. aureus. It can be concluded that curcumenol played an important contribution to antibacterial activity toward Gram-negative (S. typhi and E. coli) in $C$. aeruginosa rhizomes.

\section{ACKNOWLEDGMENT}

This work was supported by research grant from Department of Chemistry, Institut Pertanian Bogor 2017.

\section{REFERENCES}

1. Pramono, In Paper Presented in Multi-Stakeholder Dialogue on Trade, Intellectual Property, and Biological Resources in Asia, BRAC Centre for Development, Rajendrapur, Bangladesh (2002).

2. S. Hartini, J. Indones. Med. Plants., 7(1), 1(2001).

3. K. I. P. Sari, Periadnadi and N. Nasir, J. Bio. UA, 2(1), 20(2013).

4. N. Suphrom, G. Pumthong, N. Khorana, N. Waranuch, N. Limpeanchob and K. Ingkaninan, Fitoterapia, 83(5), 864(2012), DOI: 10.1016/j.fitote.2012.03.017

5. O. Theanphong, W. Mingvanish and C. Kirdmanee, BHST, 13(1), 6(2015).

6. M. Rahman, Thesis, Department of Biochemistry, Institut Pertanian Bogor, Bogor, West Java, Indonesa (2016).

7. S. Jose and T. D. Thomas, Int. J. Green Pharm., 8(1), 65(2014), DOI: 10.4103/0973-8258.126828

8. N. X. Dung, N. T. B. Tuyet and P. A. Leclercq, J. Essent. Oil Res., 7(6), 657(1995), DOI: 10.1080/10412905.1995.9700522

9. S. Simoh and A. Zainal, Asian Pac. J. Trop. Biomed., 5(5), 412(2015), DOI: 10.1016/S22211691(15)30378-6

10. H. Diastuti, Y. M. Syah, L. D. Juliawaty and M. Singgih, Indones. J. Chem., 14(1), 32(2014), DOI: 10.22146/ijc. 803

11. H. Diastuti, Y. M. Syah, L. D. Juliawaty and M. Singgih, Alchemy Jurnal Penelitian Kimia, 12(2), 103(2016), DOI: 10.20961/alchemy.v12i2.1726

12. N. Nurhayati, Thesis, Departement of Chemistry, Universitas Airlangga, Surabaya, East Java, Indonesia (2010).

13. A. Pangemanan, Fatimawali and F. Budiarso, Jurnal e-Biomedik, 4(1), 81(2016).

14. A. R. Mashita, Saintika Medika, 10(2), 138(2014), DOI: 10.22219/smumm.Vol10.No2.\%25p

15. O. A. A. Hamdi, L. J. Ye, M. N. A. Kamarudin, H. Hazni, M. Paydar, C. Y. Looi, J. A. Shilpi, H. A. Kadir and K. Awang, Rec. Nat. Prod., 9(3), 349(2015).

16. W. W. Davis and T. R. Stout, Appl. Microbiol., 22(4), 666(1971).

[RJC-2076/2018] 